\title{
New records of three species of nematodes in Cerdocyon thous from the Brazilian Pantanal wetlands
}

\author{
Novos registros de três espécies de nematoides em Cerdocyon thous do Pantanal brasileiro \\ Ana Paula Nascimento Gomes ${ }^{1}$; Natalie Olifiers ${ }^{1}$; Michele Maria dos Santos $^{1}$; Raquel de Oliveira Simóes ${ }^{1 *}$; \\ Arnaldo Maldonado Júnior ${ }^{1}$
}

\begin{abstract}
${ }^{1}$ Laboratório de Biologia e Parasitologia de Mamíferos Silvestres Reservatórios, Instituto Oswaldo Cruz,
Fundaçáo Oswaldo Cruz - FIOCRUZ, Rio de Janeiro, RJ, Brasil
\end{abstract}

Received April 6, 2015

Accepted June 25, 2015

\begin{abstract}
We report the occurrence of nematodes collected from the gut of roadkilled crab-eating foxes (two adult males and one juvenile female), Cerdocyon thous (Linnaeus, 1766), found on the BR 262 highway in Mato Grosso do Sul state, Brazil in 2011. Three helminth species were identified: Ancylostoma buckleyi, Pterygodermatites (Multipectines) pluripectinata, and Ascaridia galli. These nematodes are reported for the first time to infect $C$. thous from the Brazilian Pantanal wetlands, thereby expanding their geographical distribution.
\end{abstract}

Keywords: Helminths, nematodes, crab-eating fox, Pantanal.

\section{Resumo}

Este estudo relata a ocorrência de nematoides coletados no sistema digestório de cachorros-do-mato Cerdocyon thous (Linnaeus, 1766) encontrados atropelados na rodovia BR 262, no Estado do Mato Grosso do Sul, Brasil, em 2011. Três espécies foram identificadas: Ancylostoma buckleyi, Pterygodermatites (Multipectines) pluripectinata e Ascaridia galli. A ocorrência destes nematoides foi registrada pela primeira vez em $C$. thous no bioma Pantanal, ampliando a distribuição geográfica destes helmintos parasitos em C. thous.

Palavras-chave: Helmintos, nematoides, cachorro-do-mato, Pantanal.

\section{Introduction}

Studies of helminths in wild species are important when performing an inventory of species diversity and when determining the risk that parasites may pose to public health (MARTINS et al., 2004). However, for most wild species, there is still a lack of information regarding helminth fauna. Even widespread and abundant species such as the crab-eating fox (Cerdocyon thous) have relatively poorly known helminth fauna.

The crab-eating fox is a medium-sized canid ( 4 to $11 \mathrm{~kg}$ ) found throughout most of South America (BERTA, 1982; COURTENAY \& MAFFEI, 2004; BIANCHI et al., 2014). In Brazil, it can be found in the Cerrado, Pantanal, Caatinga, and Atlantic Rainforest, with the exception of the Amazon basin (COURTENAY \& MAFFEI, 2004). It is one of the most common roadkilled species in Brazil (BEISIEGEL et al., 2013); in the Pantanal biome, it is particularly abundant (TROLLE \& KÉRY, 2005; BIANCHI, 2009; TOMAS et al., 2010). This canid can serve as the host of several

*Corresponding author: Raquel de Oliveira Simōes. Laboratório de Biologia e Parasitologia de Mamíferos Silvestres Reservatórios, Instituto Oswaldo Cruz, Fundação Oswaldo Cruz - FIOCRUZ, Avenida Brasil, 4365, Manguinhos, CEP 21040-360, Rio de Janeiro, RJ, Brasil.

e-mail: raquel83vet@gmail.com parasites and it may play an important role in maintaining the biological cycle of helminths, especially given its generalist habits, tolerance to anthropogenic disturbances, and interaction with other wild and domestic species (COURTENAY \& MAFFEI, 2004; CURI, 2005).

There are reports of nematodes infecting $C$. thous in different Brazilian biomes; however, the majority of studies have concentrated on the Atlantic Forest and Caatinga biomes (VICENTE et al., 1997; SANTOS et al., 2003; DUARTE, 2007; GRIESE, 2007; VIEIRA et al., 2008; BRANDÁO et al., 2009; LIMA, 2009; RIBEIRO et al., 2009; MAGALHÁES-PINTO et al., 2011; LIMA et al., 2013). In the Pantanal wetlands, some nematodes have been reported in $C$. thous, such as Aelurostrongylus sp., Angiostrongylus sp., Dirofilaria repens, and Dirofilaria sp. (TRAVASSOS \& FREITAS 1943; NORONHA et al., 2002; VIEIRA et al., 2008), but the helminths fauna are expected to be comprised of many more helminths than the few that have previously been described.

In the present paper, we report the occurrence of nematodes in the crab-eating fox from the Pantanal wetlands, Mato Grosso do Sul state, Brazil. The Pantanal is the largest wetland in the world 
$\left(147,574 \mathrm{~km}^{2}\right)$, and it features seasonal floods that vary with local rainfall and flooding of the Paraguay River (RODELA, 2006). Local climatic conditions are divided into two distinct seasons, the wet (May to October) and dry (November to April) seasons (RODELA, 2006). The Pantanal biome shows highly diverse natural habitats and species, presenting with a high density of vertebrates (TOMAS et al., 2010; ALHO et al., 2011; ALHO \& SABINO, 2011).

\section{Materials and Methods}

In October and November of 2011, we travelled along the BR 262 highway between the cities of Corumbá and Campo Grande (Mato Grosso do Sul state, Brazil) for 30 times. The trips along the highway started early in the morning in order to collect fresh carcasses. Once found, roadkilled animals were placed in plastic bags in a recipient with ice and then necropsied at the local Center of Control of Zoonoses (CCZ) localized in Aquidauana, Mato Grosso do Sul municipality. Three roadkilled crab-eating fox (two adult males and one juvenile female) were found. Their nematodes were collected from the intestine, washed in saline solution $(\mathrm{NaCl} 0.85 \%)$, and stored in $70 \%$ ethanol. At the laboratory, the specimens used for morphological characterization were clarified in lactophenol and observed using a Zeiss Standard 20 light microscope. The general identification of helminths was primarily based on their morphological features, according to Vicente et al. (1997), Anderson et al. (2009), and specific taxonomic descriptions. The specimens were deposited in the Helminthological Collection of the Institute Oswaldo Cruz (CHIOC), Rio de Janeiro, Brazil. Animal procedures were approved by the Instituto Chico. The minimum and maximum measurements are given in millimeters for paratype specimens, followed by the mean in parentheses. Mendes de Conservação da Biodiversidade - ICMBio (SISBIO licença \# 30248-1).

Given that only one female of Ascaridia galli was recovered, identification based on morphological features was not possible. We thus performed a molecular analysis. Total genomic DNA was then extracted using the QIAamp DNA mini Kit extraction kit (Qiagen, Venlo, The Netherlands). DNA amplification by polymerase chain reaction (PCR) was conducted using the primers Physa_F 5'GCGAACGGCTCATTATAACA3' and Physa_R 5'AATTTCACCTCTCACGCA3' designed with the CLC Main Workbench for the $18 \mathrm{~S}$ ribosomal gene. PCR amplifications were performed in a total volume of $50 \mu \mathrm{l}$, including $5 \mu \mathrm{l} 10 \times$ buffer, $5 \mu \mathrm{l}$ of each dNTP $(10 \mathrm{mM}), 10 \mu \mathrm{l}$ of each primer $(1 \mathrm{pmol} / \mu \mathrm{l})$, $0.3 \mu \mathrm{l}$ of Taq polymerase $(5 \mathrm{U} / \mathrm{ml}), 2.5 \mu \mathrm{MgCl}_{2}(50 \mathrm{mM})$, and $2 \mu \mathrm{l}$ of total genomic DNA. The thermocycler was programmed to incubate the samples for $2 \mathrm{~min}$ at $95^{\circ} \mathrm{C}$, followed by 39 cycles at $95^{\circ} \mathrm{C}$ for $30 \mathrm{~s}, 54^{\circ} \mathrm{C}$ for $30 \mathrm{~s}, 72^{\circ} \mathrm{C}$ for $1 \mathrm{~min}$, and a final extension at $72{ }^{\circ} \mathrm{C}$ for $7 \mathrm{~min}$. In addition, we used a primer cocktail which amplifies mitochondrial gene cytochrome c oxidase subunit I (COI) (PROSSER et al., 2013): NemF1-TGTAAAA CGACGGCCAGTCRACWGTWAATCAYAARAATATTGG, NemF2-TGTAAAACGACGGCCAGTARAGATCTAATCAT AAAGATATYGG, NemF3-
TGTAAAACGACGGCCAGTARAGTTCTAATCATAAR GATATTGG, NemR1-CAGGAAACAGCTATGACTAAACTTC WGGRTGACCAAAAAATCA, NemR2-CAGGAAACAGCTATG ACTAWACYTCWGGRTGMCCAAAAAAYCA, and NemR3-CAG GAAACAGCTATGACTAAACCTCWGGATGACCAAAAAATCA. The PCR conditions were as described in Prosser et al. (2013). The reaction products were separated by electrophoresis on $1.5 \%$ agarose gel stained with ethidium bromide and examined by ultraviolet transillumination and bi-directionally sequenced using M13F andM13R as sequencing primers (PROSSER et al., 2013). Amplified products were purified using the QIAquick PCR Purification Kit (Qiagen). Sequencing reactions were performed using an ABI Prism Dye Terminator Cycle Sequencing Core Kit (Applied Biosystems; Thermo Fisher Scientific, Waltham, MA, USA). Sequences were assembled using the ChromasPro (version 1.5) software (TECHNELYSIUM, 2014). The accuracy of data was confirmed by bi-directional sequencing. A BLAST search (version 2.2.30; http://blast.ncbi.nlm.nih.gov/Blast.cgi) was performed to search for similarities with the obtained sequences and the previously deposited sequences in the GenBank database. The results were analyzed by maximum identity percentage.

\section{Results}

The present study reports three species of nematode collected from intestine of three roadkiller crab eating-fox: Ancylostoma buckleyi, Pterigodermatites (Multipectines) pluripectinata and Ascaridia galli and each species are described below.

\section{Ancylostomatidae}

Ancylostoma buckleyi Le Roux and Biocca, 1957 (Figures 1 and 2). Type host: Cerdocyon thous Linnaeus, 1766.

Common name: crab-eating fox.

Type locality: BR 262, Mato Grosso do Sul state, Brazil (S20 28.049`W055 12.126').

Site of infection: small intestine.

Specimens deposited: CHIOC 35869.

Male and female specimens have a globular buccal capsule consisting of three pairs of ventrolateral teeth and two pairs of dorsolateral teeth (Figure 1).

Male (based on four specimens): Body, 3.12-4.12 (3.60) long and $0.25-0.38(0.31)$ wide; buccal capsule, 0.15-0.16 (0.15) long and 0.09-0.13 (0.11) wide; and esophagus, 0.66-0.90 (0.81) long $(\mathrm{n}=3)$. The posterior end has a caudal bursa with two symmetric lobes, and each one features six rays: one ventroventral, one ventrolateral, one mediolateral, one lateral-dorsal, one dorsal-posterior, and one dorsal that is divided into two smaller branches (Figure 2). Long and thin spicules 0.96-1.00 (0.98) in length $(\mathrm{n}=2)$ were evident. A gubernaculum is present, being 0.11-0.12 (0.11) long ( $\mathrm{n}=2)$ (Figure 2).

Female (based on two specimens): Body 5.37-6.65 (6.01) long and $0.22-0.38(0.31)$ wide. The buccal capsule is $0.16-0.17(0.17)$ 

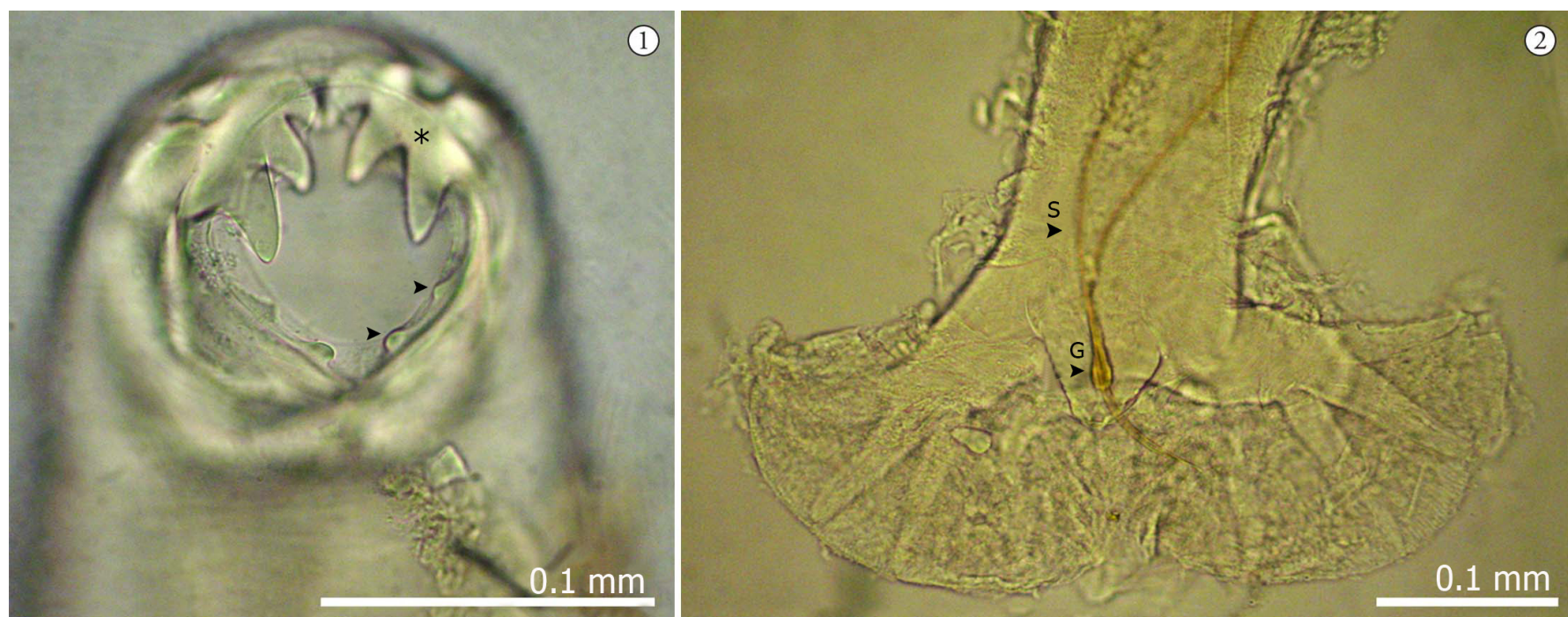

Figures 1-2. (1) Anterior part of male Ancylostoma buckleyi showing three pairs of ventrolateral teeth $\left(^{*}\right)$ and two pairs of dorsolateral teeth in the buccal capsule (arrow). (2) The posterior end of the male showing the copulatory bursa with the filiform spicule and gubernaculum (arrow). S-spicule, G- gubernaculum.

long and $0.13-0.14(0.14)$ wide, and the esophagus is $0.96-0.97$ (0.97) long.

\section{Riticulariidae}

\section{Pterygodermatites (Multipectines) pluripectinata \\ Hoppe et al., 2010 (Figures 3 and 4).}

Specimens deposited: CHIOC 35871.

Male (based on one specimen): The total body length is 4.66 and the total width is 0.24 . The buccal capsule is 0.07 long and 0.05 wide. The posterior end bears caudal alae, with three pairs of precloacal papillae, six pairs of postcloacal, penduculated papillae, and one pair of sessile papillae at the end of the tail. The spicules are thin, elongated, and are of the same size (0.12 long); a gubernaculum is absent (Figure 3 and 4 ).

Female (based on two specimens): The total body length is 5.62-6.48 (6.05) and the total width is $0.25-0.26(0.26)(\mathrm{n}=2)$. The buccal capsule is $0.08-0.09$ (0.08) long and 0.03-0.05 (0.04) wide (Figure 3), and the total length of the esophagus is 2.01-2.2 (2.1). There are two subventral rows along the body with $130-150$ cuticular processes. The vulva is $2.14-2.27$ (2.20) long from the anterior end. The tail is thin, showing a subterminal anus that is $0.14-0.20(0.17)$ long at the posterior end.

\section{Ascarididae}

Ascaridia galli (Schrank, 1788) Freeborn, 1923 (Figures 5 and 6). Specimens deposited: CHIOC 35870.

The findings are based on two female specimens collected from the gut of crab-eating foxes. These specimens have long bodies with transversal ridges that are 35.64-55.47(45.56) long and $0.86-0.91(0.88)$ wide.
In the anterior end, three lips without teeth were observed (Figure 5); the esophagus was $2.72(\mathrm{n}=1)$ long, and there was a thin tail with a subterminal anus (Figure 6). These characteristics allowed us to identify that the specimen was from the family Ascarididae. However, species identification was based on molecular analysis, which was performed by establishing consensus with partial sequences of the $18 \mathrm{~S}$ small subunit ribosomal RNA (rRNA) gene and mitochondrial gene COI. The identification based on $18 \mathrm{~S}$ rRNA showed that the specimen shared $99 \%$ of its maximum identity with $A$. galli when compared with specimen number EF180058 deposited in GenBank (NADLER et al., 2007); it also shared $100 \%$ of the maximum identity with the COI gene when compared with the haplotype obtained from chickens from an organic farm in Europe (KATAKAM et al., 2010). The sequences of $A$. galli in the present study were submitted to GenBank under the previously established accession numbers KP982856 and KP982857 for the COI gene sequence and $18 \mathrm{~S}$ rRNA sequence, respectively.

\section{Discussion}

Although helminth parasites of $C$. thous have been previously described in different biomes from Brazil - including the Pantanal wetlands - such records are still scarce. In this manuscript, we reported for the first time three nematode species in the Pantanal biome, thereby expanding upon the geographical distribution of these helminth species. Likewise, in another animal found dead in the Nhumirim Ranch, Pantanal, we have recently found a new species of Acanthocephala (GOMES et al., 2015). These findings highlight how poor our knowledge currently is regarding the species that parasitize wild mammals in Brazil.

The genus Ancylostoma has been frequently reported in South American Canidae and Procyonidae, with high prevalence rates in domestic and wild dogs (LABRUNA et al., 2006; 

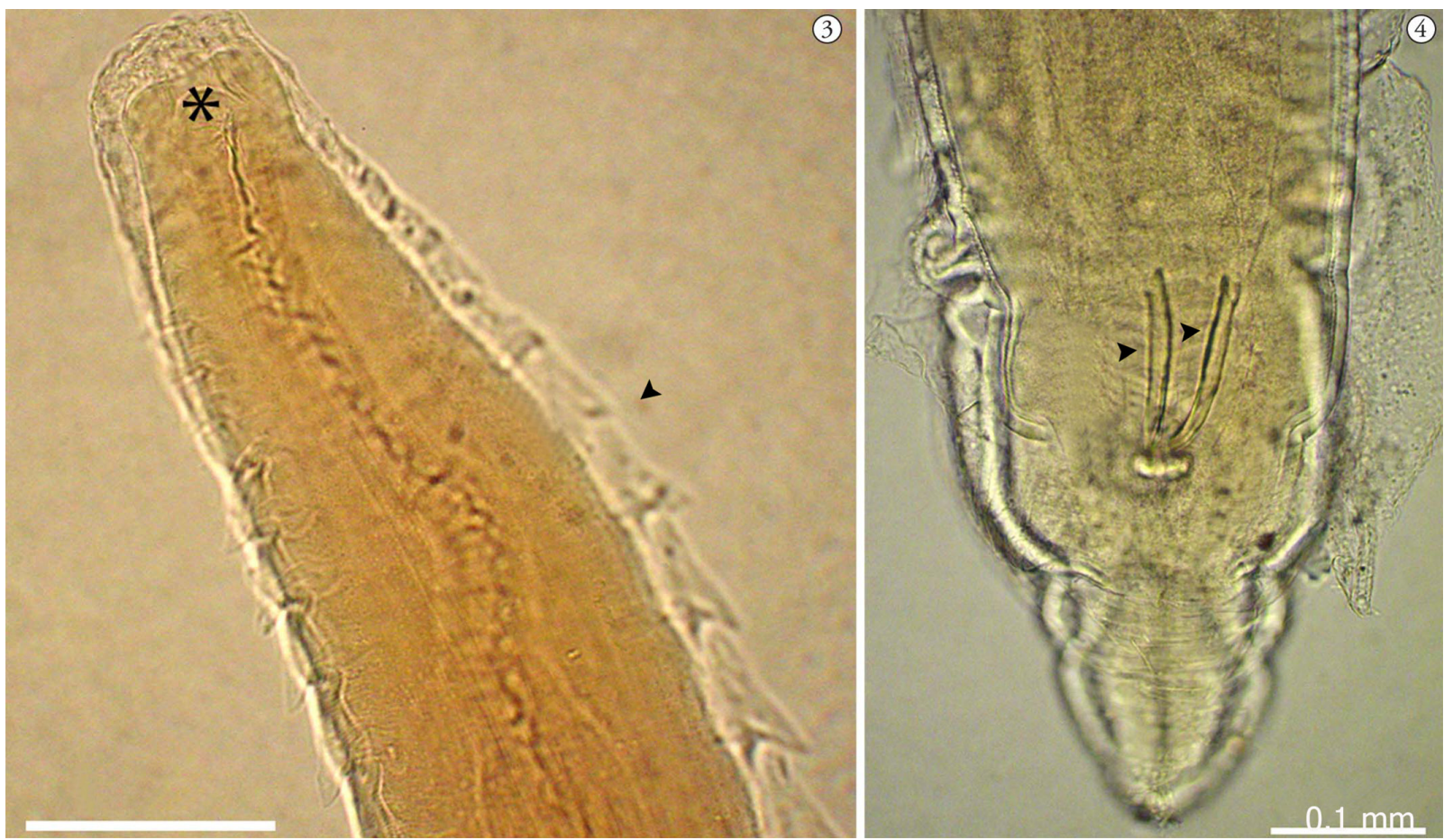

Figures 3-4. (3) Anterior part of male Pterygodermatites (Multipectines) pluripectinata showing that the buccal capsule is dorsally inclined $\left(^{*}\right)$ with lateral spines in the body. (4) Posterior end of the male showing two spicules with the same shape and size (arrow).
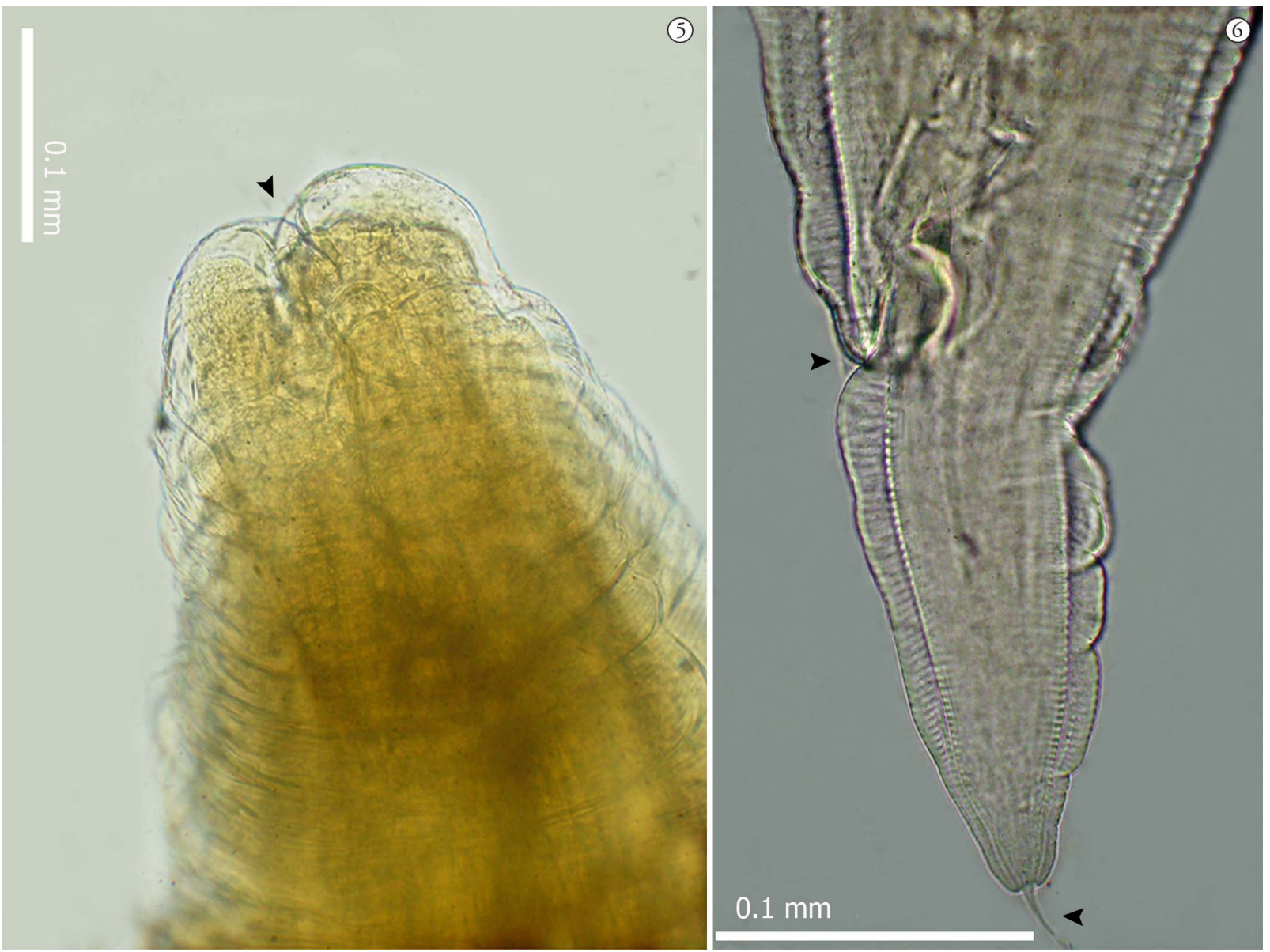

Figures 5-6. (5) Anterior part of the Ascaridia galli female showing three prominent lips. (6) Posterior end of the female showing a subterminal anus (arrow) and a spine at the end of the tail (arrow). 
SANTOS et al., 2012). The species most commonly recorded are $A$. caninum (Ercolani, 1859), A. bidens (Molin, 1861, Freitas 1851) and $A$. braziliense (Faria 1910); however, recent studies have reported infections by $A$. buckleyi (LE ROUX \& BIOCCA, 1957) in C. thous. A. buckleyi was described parasitizing Puma concolor (puma) in Argentina by Le Roux \& Biocca (1957). Later, the species was reported in dogs from Australia, as well as in wild canids in Colombia and Panama (THATCHER, 1971; SETASUBAN, 1976). The first finding of A. buckleyi in a wild canid in Pernambuco, Brazil was reported by Padilha \& Duarte (1980); it was later reported in crab-eating foxes from Itatinga, São Paulo state (SANTOS et al., 2003); Juiz de Fora, Minas Gerais state (DUARTE, 2007); and Patos, Paraíba state (LIMA et al., 2013). The presence of three pairs of ventrolateral teeth and two pairs of dorsolateral teeth in the buccal capsule distinguish this species from $A$. braziliense, A. caninum, A. tubaeformae, and A. pluridentatum (VICENTE et al., 1997).

The genus Pterygodermatites was created with the type-species Pterygodermatites plagiostoma Weld, 1861, although this species was allocated in the genus Rictularia Froelich, 1802 (QUENTIN, 1969). In the same year, Quentin (1969) revised the Rictulariidae family and established two genera (Rictularia and Pterygodermatites) based on their morphological characteristics, such as the buccal capsule position, the number of esophageal teeth, the number and position of caudal papillae, and the number of prevulvar spines (ANDERSON et al., 2009). In South America only three species of the subgenus Multipectines have been reported: $P$. (Multipectines) affinis (Jägerskiöld, 1904) Quentin, 1969 in crab-eating foxes in the Atlantic Forest and Caatinga biome in Brazil (DUARTE, 2007; LIMA, 2009); P. (Multipectines) cahirensis (Jägerskiöld, 1909) Quentin, 1969 in Geoffroy's cat Leopardus geoffroyi (D'Orbigny and Gervais, 1844) from Argentina (BELDOMENICO et al., 2005); and $P$. (Multipectines) pluripectinata in $C$. thous from Caatinga in Brazil (HOPPE et al., 2010). The subgenus Pterygodermatites (Multipectines) was described parasitizing C. thous with two species: P. (Multipectines) pluripectinata (HOPPE et al., 2010), and $P$. (Multipectines) affinis (LIMA, 2009). Some authors suggest that $P$. (Multipectines) affinis was introduced by $C$. thous in South America because there is fossil evidence of this genus parasitizing ancestral canids in North and Central America. According to these authors, the species would have spread to South America via ancestral dogs (WANG \& TEDFORD, 2007; HOPPE et al., 2010). In this present study, we identified and described $P$. (M) pluripectinata given that it had 130-150 cuticular spines (whereas the other species have up to 140 spines; Figure 3), and by the number and position of caudal papillae. These characteristics could help distinguish $P$. (M.) pluripectinata from $P$. (M.) affinis. Infection by this species probably occurs in $C$. thous due to the variety of intermediate hosts such as invertebrates, which are part of the diet of $C$. thous in the Pantanal biome (BIANCHI et al., 2014).

The nematode $A$. galli is a common species infecting domestic and wild birds worldwide, and it has also been reported in Brazil in distinct geographic regions and with a high prevalence rate in the domestic chicken, Gallus gallus domesticus (VICENTE et al., 1997). Parasitism of this species in mammals, however, is rare and there is only one record of an adult helminth in a domestic cat (Felis catus domesticus) from Rio de Janeiro, Brazil. Santos (2013) had stated that they found the eggs of $A$. galli in the feces of $C$. thous and domestic dogs in Caatinga biome, the record may be considered dubious because the identification of nematode species based on egg morphology is very difficult, unless the species shows very conspicuous eggs. Despite previous evidence, this study confirms the occurrence of this parasite in crab-eating foxes.

All parasite morphological measurements presented in this study are in accordance with those described in the literature for those parasites species, which confirms the species identification. Such measurements can also contribute to establish a more precise mean and standard deviation for important species morphological traits.

This study highlights how working with roadkilled animals can significantly add to the knowledge of the helminth fauna of wild species. We recommend that researchers place greater focus on the opportunity to describe helminth species by making use of roadkilled specimens.

\section{Acknowledgements}

We thank Rodrigo Mexas from the Image Production and Treatment Service of Oswaldo Cruz Institute (FIOCRUZ) for helping with image processing and final production; and we also thank the staff of Embrapa Pantanal for helping in the field and for making the nematode specimens available. This study received financial support from FUNDECT, EMBRAPA-MACRO, PAPES IV/IOC-FIOCRUZ, and CAPES. Arnaldo Maldonado Júnior has a fellowship from the National Council for Scientific and Technological Development (CNPq). English-language editing of this manuscript was provided by Journal Prep. We also thank Genomic Platform-DNA Sequencing (PDTIS-FIOCRUZ) for assistance with the sequencing of the samples in this study.

\section{References}

Alho CJR, Camargo G, Fischer E. Terrestrial and aquatic mammals of the Pantanal. Braz J Biol 2011;71(1 Suppl 1): 297-310. PMid:21537603.

Alho CJR, Sabino J. A conservation agenda for the Pantanal's biodiversity. Braz J Biol 2011;71(1 Suppl 1): 327-335. PMid:21537606.

Anderson RC, Chabaud AG, Willmott S, editors. Keys to the nematode parasites of vertebrates: archival volume. Wallingford: CAB International; 2009.

Beisiegel BM, Lemos FG, Azevedo FC, Queirolo D, Jorge RSP. Avaliação do risco de extinção do Cachorro-do-mato Cerdocyon thous (Linnaeus, 1766) no Brasil. Biodivers Bras 2013; 3(1): 138-145.

Beldomenico PM, Kinsella JM, Uhart MM, Gutierrez GL, Pereira J, Ferreyra HD, et al. Helminths of Geoffroy's cat, Oncifelis geoffroyi (Carnivora, Felidae) from the Monte Desert, central Argentina. Acta Parasitol 2005; 50(3): 263-266.

Berta A. Cerdocyon thous. Mamm Species 1982; 186(186): 1-4. http:// dx.doi.org/10.2307/3503974.

Bianchi RC, Campos RC, Xavier-Filho NL, Olifiers N, Gompper ME, Mourão G. Intraspecific, interspecific, and seasonal differences in the 
diet of three mid-sized carnivores in a large neotropical wetland. Acta Theriol (Warsz) 2014; 59(1): 13-23. http://dx.doi.org/10.1007/s13364013-0137-x.

Bianchi RC. Ecologia de mesocarnivoros em uma área do Pantanal Central, Mato Grosso do Sul [Tese]. Mato Grosso do Sul: Universidade Federal do Mato Grosso do Sul; 2009.

Brandão ML, Chame M, Cordeiro JLP, Chaves SAM. Diversidade de helmintos intestinais em mamíferos silvestres e domésticos na Caatinga do Parque Nacional Serra da Capivara, Sudeste do Piauí, Brasil. Rev Bras Parasitol Vet 2009;18(S1 Suppl 1): 19-28. http://dx.doi.org/10.4322/ rbpv.018e1004. PMid:20040186.

Courtenay O, Maffei L. Crab-eating fox Cerdocyon thous (Linnaeus, 1766). In: Sillero-Zubiri C, Hoffmann M, Macdonald DW, editors. Canids: foxes, wolves, jackals and dogs. Status survey and conservation action plan. Cambridge: IUCN; 2004. p. 32-38.

Curi NHA. Avaliação do estado de saúde e do risco de transmissão de doenças entre canídeos (Mammalia, Carnivora) silvestres e domésticos na região da Serra do Cipó Minas Gerais: implicaçōes para a conservaçāo [Dissertação]. Minas Gerais: Pontifícia Universidade Católica de Minas Gerais; 2005.

Duarte HF. Helmintofauna em Cerdocyon thous Linnaeus, 1766 (Carnivora: Canidae) na regiāo de Juiz de Fora, Minas Gerais [Dissertação]. Minas Gerais: Universidade Federal de Juiz de Fora; 2007.

Gomes APN, Olifiers N, Souza JGR, Barbosa HS, D'Andrea PS, Maldonado A Jr. A new acanthocephalan species (Archiacanthocephala: Oligacanthorhynchidae) from the crab-eating fox (Cerdocyon thous) in the Brazilian pantanal wetlands. J Parasitol 2015; 101(1): 74-79. http:// dx.doi.org/10.1645/13-321.1. PMid:25291295.

Griese J. Helmintofauna de vertebrados atropelados em rodovias da região de Botucatu, São Paulo [Dissertação]. São Paulo: Universidade Estadual de São Paulo; 2007.

Hoppe EGL, Lima RCA, Tebaldi JH, Nascimento AA. Pterygodermatites (Multipectines) pluripectinata n. sp. (Spirurida: Rictulariidae), a nematode parasite of the crab-eating fox Cerdocyon thous (Linnaeus, 1766) from Caatinga shrubland, Brazil. J Helminthol 2010; 84(3): 312-316. http:// dx.doi.org/10.1017/S0022149X0999071X. PMid:20056009.

Katakam KK, Nejsum P, Kyvsgaard NC, Jørgensen CB, Thamsborg SM. Molecular and parasitological tools for the study of Ascaridia galli population dynamics in chickens. Avian Pathol 2010; 39(2): 81-85. http://dx.doi.org/10.1080/03079451003599284. PMid:20390541.

Labruna MB, Pena HFJ, Souza SLP, Pinter A, Silva JCR, Ragozo AMA, et al. Prevalência de endoparasitas em cães da área urbana do município de Monte Negro, Rondônia. Arq Inst Biol (Sao Paulo) 2006; 73(2): 183-193.

Le Roux P, Biocca E. Su una nuova specie del genere Uncinaria e su due nuove specie del genere Ancylostoma. Acad Naz Lincei 1957; 22(2): 192-199.

Lima RC, Hoppe EGL, Tebaldi JH, Cruz BC, Gomes AAB, Nascimento AA. Gastrintestinal helminths of Cerdocyon thous (Linnaeus, 1766 - Smith, 1839) from the caatinga area of the Paraíba State, Brazil. Semina: Ciênc Agrár 2013; 34(6): 2879-2888.

Lima RCA. Helmintos gastrointestinais de Cerdocyon thous (Linnaeus, 1766) Smith, 1839 provenientes da área de caatinga do Estado da Paraiba, Brasil [Dissertação]. São Paulo: Universidade Estadual de São Paulo; 2009.

Magalhães-Pinto R, Knoff M, Gomes DC, Noronha D. Nematodes from Mammals in Brazil: an updating. Neotrop Helminthol 2011; 5(2): 139-183.

Martins JR, Medri IM, Oliveira CM, Guglielmone A. Ocorrência de carrapatos em Tamanduá-Bandeira (Myrmecophaga tridactyla) e Tamanduá Mirim (Tamandua tetradactyla) na Regiáo do Pantanal Sul Mato-grossense,
Brasil. Cienc Rural 2004; 34(1): 293-295. http://dx.doi.org/10.1590/ S0103-84782004000100048.

Nadler SA, Carreno RA, Mejía-Madrid H, Ullberg J, Pagan C, Houston $\mathrm{R}$, et al. Molecular phylogeny of clade III nematodes reveals multiple origins of tissue parasitism. Parasitology 2007; 134(Pt 10): 1421-1442. http://dx.doi.org/10.1017/S0031182007002880. PMid:17506928.

Noronha D, Vicente JJ, Pinto RM. A survey of new records for nematodes from mammals deposited in the Helminthological collection of the Oswaldo Cruz Institute (CHIOC). Rev Bras Zool 2002; 19(3): 945-949. http://dx.doi.org/10.1590/S0101-81752002000300032.

Padilha TN, Duarte MJF. Ancylostoma buckleyi Le Roux and Biocca, 1957 no Estado de Pernambuco, Brasil. Atas Soc Biol 1980; 21(1): 3-4.

Prosser SWJ, Velarde-Aguilar MG, León-Règagnon V, Hebert PDN. Advancing nematode barcoding: a primer cocktail for the cytochrome $c$ oxidase subunit I gene from vertebrate parasitic nematodes. Mol Ecol Resour 2013; 13(6): 1108-1115. PMid:23433320.

Quentin JC. Essai de classificassion des Nématodes Rictulaires. Mem Mus Natn Hist Nat 1969; 54(1): 57-115.

Ribeiro CT, Verocai GG, Tavares LER. Dioctophyme renale (Nematoda, Dioctophymatidae) infection in the crab-eating fox (Cerdocyon thous) from Brazil. JWildl Dis 2009; 45(1): 248-250. http://dx.doi.org/10.7589/00903558-45.1.248. PMid:19204359.

Rodela LG. Unidades de vegetação e pastagens nativas do pantanal da Nhecolândia, Mato Grosso do Sul [Tese]. São Paulo: Universidade de São Paulo; 2006.

Santos JDO. Diversidade de helmintos intestinais em cães domésticos (Canis familiaris Linnaeus, 1758) e de raposas (Cerdocyon thous Linnaeus, 1766) no semiárido do Nordeste do Brasil e implicações para a saúde [Dissertação]. Rio de Janeiro: Escola Nacional de Saúde Pública, Fundação Oswaldo Cruz; 2013

Santos JLC, Magalhães NB, Santos HA, Ribeiro RR, Guimarães MP. Parasites of domestic and wild canids in the region of Serra do Cipó National Park, Brazil. Rev Bras Parasitol Vet 2012; 21 (3): 270-277. http:// dx.doi.org/10.1590/S1984-29612012000300016. PMid:23070438.

Santos KR, Catenacci LS, Pestelli MM, Takahira RK, Lopes RS, Silva RJ. First report of Ancylostoma buckleyi Le Roux and Biocca, 1957 (Nematoda: Ancylostomatidae) infecting Cerdocyon thous Linnaeus, 1766 (Mammalia: Canidae) from Brazil. Rev Bras Parasitol Vet 2003; 12(4): 179-181.

Setasuban P. Morphology of Ancylostoma buckleyi Le Roux and Biocca, 1957 in dogs from Cairns, North Queensland, Australia. Southeast Asian J Trop Med Public Health 1976; 7(1): 45-49. PMid:1027107.

Technelysium. Software for DNA Sequencing. ChromasPro [online]. South Brisbane: Technelysium Pty Ltd. [cited 2014 Dec 17]. Available from: http://www.technelysium.com.au/ChromasPro.html

Thatcher VE. Some hookworms of the genus Ancylostoma from Colombia and Panama. Proc Helminthol Soc Wash 1971; 38(1): 109-116.

Tomas WM, Cáceres NC, Nunes AP, Fischer E, Mourão G, Campos Z. Mammals in the Pantanal wetland, Brazil. In: Junk WJ, Silva CJ, Cunha CN, Wantzen KM, editors. The Pantanal: ecology, biodiversity and sustainable management of a large Neotropical seasonal wetland. Moscow: Pensoft Publishers; 2010. p. 565-598.

Travassos L, Freitas JFT. Relatório da sétima excursão científica do Instituto Oswaldo Cruz, realizada a zona da Estrada de Ferro Noroeste do Brasil, em maio de 1942. Mem Inst Oswaldo Cruz 1943; 38(3): 385-412. http:// dx.doi.org/10.1590/S0074-02761943000300007. 
Trolle M, Kéry M. Camera-trap study of ocelot and other secretive mammals in the northern Pantanal. Mammalia 2005; 69(3-4): 405-412. http://dx.doi.org/10.1515/mamm.2005.032.

Vicente JJ, Rodrigues HO, Gomes DC, Pinto RM. Nematóides do Brasil. Parte V: nematóides de mamíferos. Rev Bras Zool 1997; 14(S1): 1-452.
Vieira FM, Luque JL, Muniz-Pereira LC. Checklist of helminth parasites in wild carnivore mammals from Brazil. Zootaxa 2008; 1721: 1-23.

Wang X, Tedford RH. Evolutionary history of canids. In: Jensen P, editor. The behavioral biology of dogs. Trowbridge: Cromwell Press; 2007. p. 3-10. http://dx.doi.org/10.1079/9781845931872.0003. 